\title{
Taxonomic diversity and ethnobotanical characteristics of the family Lamiaceae of Swat, Khyber Pakhtunkhwa, Pakistan

\author{
Izhar Ahmad ${ }^{1}$, Samin Jan ${ }^{1}$, Afroza Begum ${ }^{2}$ and Sher Wali ${ }^{3 *}$
}

1. Department of Botany, Islamia College Peshawar

2. Biology Department, University of York, UK, YO10 5DD

3. Department of Botany, Shaheed Benazir Bhutto University Sheringal, Dir (U)

*Corresponding author's email: sherwali@sbbu.edu.pk

Citation

Izhar Ahmad, Samin Jan, Afroza Begum and Sher Wali. Taxonomic diversity and ethnobotanical characteristics of the family Lamiaceae of Swat, Khyber Pakhtunkhwa, Pakistan. Pure and Applied Biology. Vol. 4, Issue 4, 2015, pp 465-470. http://dx.doi.org/10.19045/bspab.2015.44003

Received: $18 / 05 / 2015$

Revised: 04/11/2015

Accepted: 13/11/2015

\section{Abstract}

A total of 35 species belonging to 21 genera of the family Lamiaceae were collected from the research area. The plants were categorized on the basis of their morphological characteristics and ethnobotanical uses. The plants were classified and described in semi-technical language. Bracket keys were constructed to ensure their easy classification and description. Nepeta and Salvia were found to be the dominant genera each represented by five (5) species. Mentha was the next dominant genus with three (3) species followed by Ajuga, Leucas, Ocimum, and Stachys each with two (2) species. While a single species was contributed by all the other genera. Ethnobotanically almost all the plants had more than one uses by the locality people. Most of the plants are important ethnomedicinally. Despite various ailments members of the family Lamiaceae collected from the research area are also used for various traditional and religious aspects.

Keywords: Taxonomic; diversity; Lamiaceae; enthnobotanical.

\section{Introduction}

The research area, Swat Valley, is located between 340-31'- 55" and $350-53^{\prime}-40^{\prime \prime}$ north latitudes and $710-44^{\prime}-40^{\prime \prime}$ and $720-$ $47^{\prime}-15^{\prime \prime}$ east longitudes. The climate of the area has been affected by a number of factors. The general topography of the land is undulating cut off by small and big streams. The shape of the valley is a broad "V". The vegetation shows wide variation depending upon the ecological conditions of the area. There are very possible type of vegetation according to the height of different places in the research area and the climatic conditions prevailing there.
A description of the genera and species of the order labiatae was provided [1].A new species of Salvia from Baluchistan and made a complete revision of the family was described [2]. A survey was made on the system of classification of the genus Salvia [3].11 genera in the alphabetical order from Ajuga to Lallemantia were studied [4].Morphology of some representative genera was studied in the tribe Saturejeae (Lamiaceae) [5]. The essential oil yield of Lamiaceae plants in Greece was evaluated [6]. Wood anatomy of Lamiaceae and quantitative and qualitative data on the wood anatomy was formulated [7]. The botanical 
characteristics, nomenclature and systematic, ornamental values and other uses of the Genus Thymus were investigated [8].Leaf content of macro and micro element was evaluated for 147 species in the family Lamiaceae [9]. Trudel and Morton [10] studied taxonomy and pollen morphology in the North American Labiatae. Ameluxen and inlert [11] studied filament bundle in Mentha piperata. Brenner et al. [12] studied the uses and genetic resources of Perilla frutescence. Budanstev and Lobova [13] described fruit surface ultrastructure in 89 Nepeta species by scanning electron microscopy. Circella [14] made a comparative account of biology, growth and productivity of the different taxa and ecotypes of the genus Origanum. Ramamoorthy and Elliott [15] described the diversity, distribution, endemism and evolution of the Mexican Lamiaceae. AbuAbu-Asaband Cantino [16] implicated systematically pollen morphology in the subfamilies Lamioideae and Pogostemonoideae. Maffie [17] analyzed that leaf was alkan in Lamiaceae and four other families. Ryding [18] studied the pericarp in 11 species of the sub-family Pogostemonoideae. Pace and Piccaglia [19] characterized the essential oil of a wild Italian endemic sage, Salvia officinalis. Smitherman et al. [20] described that plants have been used as folk medicine throughout the world. Various studies have been carried out on the ethnobotany of medicinal and other useful plants in different parts of Pakistan [21, 22, 23, 24]. Some medicinal and ethnobotanical studies also have been carried out in the nearby regions of the study site. Shinwari et al. $[25,26]$ worked on the ethnobotanical studies of Swat. Ali and Qaisar [27] listed the indigenous use of 83 taxa from Chitral district.

\section{Materials and Methods}

Several trips were made to the upper and lower Swat for the collection of plants belonging to the family Lamiaceae. Photographs of all the collected plants were taken at the time of collection. The plant specimens collected were placed in the blotting papers and old newspapers; changed regularly each at 24 hours interval, for the removal of the moisture and subsequently places in the plant presser to avoid any shrinking and wrinkling. The dried plant specimens were treated with Naphthalene powder to keep them protected from any fungal and insect attacks. The dried and preserved specimens were mounted on standard herbarium sheets. Ecological information was noted at the time of the collection of the plants. The mounted specimens were identified on the basis of morphological characteristics of the vegetative and floral parts of the plants with help of flora of Pakistan and some other floras available electronically. All the voucher specimens were submitted to the herbarium of the Department of Botany, Islamia College Peshawar. Data regarding the ethnobotanical characteristics of the plants collected through oral interviews and questionnaires.

\section{Results and Discussion}

The plants belonging to family lamiaceaeare widely distributed throughout the research areae. A total of 35 species belonging to 21 genera of the family Lamiaceae were collected from the research area. Nepeta and Salvia were found to be the dominant genera each represented by five (5) species. Mentha was the next dominant genus with three (3) species followed by Ajuga, Leucas, Ocimum, and Stachys each with two (2) species. While a single species was contributed by all the other genera. The plants were categorized on the basis of their morphological characteristics and ethnobotanical uses. The plants were classified and described in semitechnical language. Bracket keys were constructed to ensure their easy classification and description. All the representative genera, species and infra specific categories were described morphologically and their diagnostic features were recorded. 
Ethnobotanically almost all the plants had more than one uses by the locality people. Most of the plants are important ethnomedicinally. Despite various ailments members of the family Lamiaceae collected from the research area are also used for various traditional and religious aspects. The plants have diverse uses in a number of therapeutic classes of disorders. Most of the plants recorded are used in gastric and stomach disorders. The current study provides recipes for all the plants reported for the family Lamiaceae from the resear4ch are. These recipes are mostly in accordance with $[28,29,30]$. All the information related to ethnomedicinal uses of the plants belonging to the family Lamiaceae were recorded in a comprehensive table (Table 1).

Table 1. Representative members of the family Lamiaceae with their ethnobotanical uses

\begin{tabular}{|c|c|c|c|c|}
\hline S. No. & Genus & Botanical Name & Part Used & Ethnomedicinal Uses \\
\hline \multirow[t]{2}{*}{1.} & \multirow[t]{2}{*}{ Ajuga L. } & $\begin{array}{l}\text { 1. Ajuga integrifolia } \text { Buch.- } \\
\text { Ham. }\end{array}$ & $\begin{array}{l}\text { Leaves and } \\
\text { stems }\end{array}$ & Paste of wounds and tumors \\
\hline & & 2. Ajuga parviflora Benth. & Leaves & Respiratory disorders \\
\hline 2. & $\begin{array}{l}\text { Clinopodium } \\
\text { L. }\end{array}$ & $\begin{array}{l}\text { 3. Clinopodium debile } \\
\text { (Bunge) Kuntze }\end{array}$ & Whole Plant & Forage and healing wounds \\
\hline 3. & Hyssopus L. & 4. Hyssopusofficinalis L. & $\begin{array}{l}\text { Flowers, leaves } \\
\text { and essential oil }\end{array}$ & $\begin{array}{c}\text { Expectorant and antiviral } \\
\text { activities }\end{array}$ \\
\hline 4. & $\begin{array}{c}\text { Isodon } \\
\text { (Schrad. ex } \\
\text { Benth.) Spach } \\
\end{array}$ & $\begin{array}{l}\text { 5. Isodon rugosus (Wall. ex } \\
\text { Benth.) Codd }\end{array}$ & Whole Plant & $\begin{array}{c}\text { Antipyretic and an anti- } \\
\text { diarrheal }\end{array}$ \\
\hline 5. & Lamium L. & 6. Lamium album $\mathrm{L}$. & $\begin{array}{l}\text { Leaves and } \\
\text { young stems }\end{array}$ & $\begin{array}{c}\text { Trauma, fracture, paralysis, } \\
\text { hypertension anduterine } \\
\text { hemorrhage. }\end{array}$ \\
\hline \multirow{2}{*}{6.} & \multirow{2}{*}{ Leucas R. Br. } & $\begin{array}{l}\text { 7. Leucascephalotes (Roth) } \\
\text { Spreng. }\end{array}$ & Whole Plant & $\begin{array}{l}\text { Antioxidant, analgesic and } \\
\text { anti-inflammatory }\end{array}$ \\
\hline & & $\begin{array}{l}\text { 8. Leucasnutans (Roth) } \\
\text { Spreng. }\end{array}$ & Whole Plant & $\begin{array}{l}\text { cough, cold, diarrhea, and } \\
\text { inflammatory skin }\end{array}$ \\
\hline 7. & Marrubium L. & $\begin{array}{ll}\text { 9. } & \text { Marrubium } \\
\text { anisodonK.Koch }\end{array}$ & Aerial Parts & Essential oil, Antioxidant \\
\hline \multirow{3}{*}{8.} & \multirow{3}{*}{ Mentha L. } & 10. Mentha longifolia (L.) L. & Roots & $\begin{array}{l}\text { Carminative and anti- } \\
\text { vomiting }\end{array}$ \\
\hline & & 11. Mentha spicata $\mathrm{L}$. & Leaves & $\begin{array}{l}\text { Salad and Making tea for } \\
\text { treating vomiting }\end{array}$ \\
\hline & & $\begin{array}{l}\text { 12. Mentha royleana Wall. } \\
\text { exBenth. }\end{array}$ & Leaves & $\begin{array}{l}\text { Antioxidant activity, } \\
\text { Antioxidant activity }\end{array}$ \\
\hline 9. & $\begin{array}{l}\text { Micromeria } \\
\text { Benth. }\end{array}$ & $\begin{array}{l}\text { 13. Micromeria biflora } \\
\text { (Buch.-Ham. ex D.Don) } \\
\text { Benth. }\end{array}$ & $\begin{array}{l}\text { Dried flowers } \\
\text { and leaves }\end{array}$ & $\begin{array}{l}\text { Antimicrobial, used as a tea, } \\
\text { flavouring in lentil soups }\end{array}$ \\
\hline \multirow{2}{*}{10.} & \multirow{2}{*}{ Nepeta L. } & $\begin{array}{l}\text { 14. Nepeta erecta (Royle ex } \\
\text { Benth.) Benth. }\end{array}$ & Leaves & laxative \\
\hline & & 15. Nepeta floccose Benth. & $\begin{array}{l}\text { Leaves and } \\
\text { flowers }\end{array}$ & $\begin{array}{l}\text { Reduce fats, temperature and } \\
\text { to stop hair fall. }\end{array}$ \\
\hline
\end{tabular}


Ahmad et al.

\begin{tabular}{|c|c|c|c|c|}
\hline & & 16. Nepeta kokanica Regel & $\begin{array}{l}\text { Leaves and } \\
\text { flowers }\end{array}$ & anthelmintic, emetic, digestive \\
\hline & & $\begin{array}{l}\text { 17. Nepeta laevigata } \\
\text { (D.Don) Hand.-Mazz. }\end{array}$ & seeds & Dysentery \\
\hline & & $\begin{array}{l}\text { 18. Nepeta podostachys } \\
\text { subsp. paulsenii (Briq.) } \\
\text { A.L.Budantzev } \\
\end{array}$ & Aerial parts & Fever, aromatic \\
\hline \multirow{2}{*}{11.} & \multirow{2}{*}{ Ocimum L. } & 19. Ocimum basilicum L. & $\begin{array}{l}\text { Leaves and } \\
\text { inflorescence }\end{array}$ & $\begin{array}{c}\text { Fragrance, to avoid } \\
\text { mosquitoes and devils effects }\end{array}$ \\
\hline & & 20. Ocimum americanum L. & $\begin{array}{c}\text { Leaves and } \\
\text { stems }\end{array}$ & Dysentery bacteria \\
\hline 12. & Origanum L. & 21. Origanum vulgare L. & Extracted oils & Dysentery bacteria \\
\hline 13. & $\begin{array}{c}\text { Rydingia } \\
\text { Scheen \& V.A. } \\
\text { Albert }\end{array}$ & $\begin{array}{l}\text { 22. Rydingia limbata } \\
\text { (Benth.) Scheen \& V.A. } \\
\text { Albert }\end{array}$ & Leaves & Wounds, gum diseases \\
\hline 14. & Phlomis L. & $\begin{array}{l}\text { 23. Phlomoides bracteosa } \\
\text { (Royle ex Benth.) } \\
\text { Kamelin \& Makhm. }\end{array}$ & Aerial parts & Forage \\
\hline 15. & $\begin{array}{l}\text { Plectranthus } \\
\text { L'Hér. }\end{array}$ & $\begin{array}{l}\text { 24. Plectranthus barbatus } \\
\text { Andrews }\end{array}$ & $\begin{array}{l}\text { Leaves and } \\
\text { flowers }\end{array}$ & $\begin{array}{c}\text { Leaves in tea and used against } \\
\text { cough and cold. Flowers are } \\
\text { used against toothache and as } \\
\text { laxative. }\end{array}$ \\
\hline 16. & Prunella L. & 25. Prunella vulgaris L. & Leaves & $\begin{array}{l}\text { Applied directly to a fresh } \\
\text { wound }\end{array}$ \\
\hline \multirow{5}{*}{17.} & \multirow{5}{*}{ Salvia L. } & 26. Salvia aegyptiaca L. & Whole Plant & $\begin{array}{l}\text { dizziness, trembling, diarrhea } \\
\text { and piles }\end{array}$ \\
\hline & & $\begin{array}{l}\text { 27. Salvia mukerjeei Bennet } \\
\text { \& Raizada }\end{array}$ & Leaves & Antiseptic and cleansing agent \\
\hline & & $\begin{array}{l}\text { 28. Salvia moorcroftiana } \\
\text { Wall. Ex Benth. }\end{array}$ & Roots & Colds and coughs \\
\hline & & $\begin{array}{l}\text { 29. Salvia nubicola Wall. ex } \\
\text { Sweet }\end{array}$ & Aerial parts & $\begin{array}{l}\text { Making pastes used as } \\
\text { emulsion }\end{array}$ \\
\hline & & 30. Salvia plebeian R.Br. & Whole plant & $\begin{array}{l}\text { astringent, diuretic and } \\
\text { vermifuge }\end{array}$ \\
\hline 18. & Scutellaria L. & $\begin{array}{l}\text { 31. Scutellaria edelbergii } \\
\text { Rech.f. }\end{array}$ & Root & Diarrhea, and inflammation. \\
\hline
\end{tabular}

\section{Authors' contributions}

Designed by: I Ahmad. Data collected by: I Ahmad \& S Wali. Data analysis: I Ahmad, A Begum, S Jan \& S Wali. Written by: I Ahmad \& S Wali.

\section{References}

1. Bentham G (1832). Labiatarum genera species. Ridgeway, London.
2. Mukerjee SK (1938). A decade of new Labiatae from India, Burma, and Tibet. Notes Bot. Gard. Edinb 19: 303-314.

3. Hurby K (1962). Key to superspecific taxa of the genus Salvia L. Preslia 34: 368373.

4. Hedge IC (1967). Studies in the Flora of Afghanistan: VI, Labiatae, conclusion 
and key to genera. Notes from the Royal Botanic Garden, Edinburgh 27: 149-173. 5. Husain SZ, Marin PD, Silic C, Qaiser M \& Petcovic B (1990). A micromorphological study of some representative genera in the tribe Saturejeae (Lamiaceae). Botanical Journal of the Linnean Society 103(1): 59-80.

6. Kokkini S, Vokou D, Karousou R, Bhattacharyya SC, Sen N \& Sethi KL (1990). Essential oil yield of Lamiaceae plants in Greece. In Proceedings of the 11th international congress of essential oils, fragrances and flavours. New Delhi, India 3: 5-12.

7. Carlquist S (1992). Wood anatomy of Lamiaceae. Aliso. 13: 309-338.

8. Harley MM, Paton A, Harley RM \& Cade PG (1992). Pollen morphological studies in tribe Ocimeae (Nepetoideae: Labiatae): I. Ocimum L. Grana 31(3): 161-176.

9. Mathe A, Lemberkovics E, Mathe IJr, Mathe I \& Hang N (1993). Production biology of Mediterranean Lamiaceae species in the temperate belt. Acta Horticulturae 344: 121-122.

10. Trudel MCG \& Morton JK (1992). Pollen morphology and taxonomy in North American Labiatae. Canadian Journal of Botany 70(5): 975-995.

11. Amelunxen F, Inlert F (1993). The Filament Bundle of Menthapiperita. Planta medica 59(1): 86-89.

12. Brenner DM (1993). Perilla: Botany, uses, and genetic resources. New Crops 322-328.

13. Budantsev AL \& Lobova TA (1997). Fruit morphology, anatomy and taxonomy of tribe Nepeteae (Labiatae). Edinburgh Journal of Botany 54(02): 183-216.

14. Circella G \& Levy A (1993). Comparative study on biology, growth and productivity of different taxa and ecotypes of genus Origanum. First world congress on medicinal and aromatic plants for human welfare, Netherlands 330: 115-121.

15. Ramamoorthy TP \& Elliott M (1993). Mexican Lamiaceae: diversity, distribution, endemism and evolution. In Ramamoorthy TP, Bye R, Lot A \& Fa JE. Biological diversity of Mexico: origins and distribution. Oxford University Press, New York 513-539.

16. Abu-Asab MS \& Cantino PD (1994). Systematic implications of pollen morphology in subfamilies Lamioideae and Pogostemonoideae (Labiatae). Annals of the Missouri Botanical Garden 653-686.

17. Maffei M (1994). Discriminant analysis of leaf wax alkanes in the Lamiaceae and four other plant families. Biochemical systematics and ecology 22(7): 711-728.

18. Ryding O (1994). Pericarp structure and phylogeny of Lamiaceae subfamily Pogostemonoideae. Nordic journal of Botany 14(1): 59-63.

19. Pace L \& Piccaglia R (1995). Characterization of the Essential Oil of a Wild Italian Endemic Sage: Salvia officinalis L. var. angustifolia Ten (Labiatae). Journal of Essential Oil Research 7(4).

20. Smitherman LC, Janisse J \& Mathur A (2005). The use of folk remedies among children in an urban black community: remedies for fever, colic, and teething of Pediatrics. 115(3): 297-304.

21. Durrani MJ \& Hussain F (2006). Ethnobotanical profile of harboi rangeland, Kalat University, Quetta, Pakistan. Pak. Int. J. Biol. Biotechnol. 2: 15-22.

22. Ibrar M, Hussain F \& Amir S (2007). Ethnobotanical studies on plant resources of Ranyal Hills, District Shangla, Pakistan. Pak. J. Bot. 39(2): 329-337. 
23. Qureshi SJ, Khan MA \& Ahmad M (2008). A survey of useful medicinal plants of Abbott abad in northern Pakistan. Trakia J. Sci. 6(4): 39-51.

24. Rahmatullah Q \& Bhatti R (2008). Ethnobotany of plants used by the people of Nara Desert, Pakistan. Fitoterapia 79(6): 468-473.

25. Shinwari ZK \& Gilani SS (2003a). Sustainable harvest of medicinal plants of Astore, Northern Pakistan. $J$. Ethnopharmacol 2: 289-298.

26. Shinwari ZK, Gilani SS \& Rehman M (2003b). Medicinal and other useful plants of Swat. In: Shinwari ZK, Khan AA and Nakaike T (Eds). Medicinal and other useful plants of District Swat, Pakistan. 34-109.

27. Ali H \& Qaisar M (2009). The Ethnobotany of Chitral Valley, Pakistan with particular reference to medicinal plants. Pak. J. Bot. 41(4): 2009-2041.

28. Ahmad M, Qureshi R, Arshad M, Khan MA \& Zafar M. (2009). Traditional herbal remedies used for the treatment of diabetes from District Attock (Pakistan). Pak. J. Bot. 41(6): 2777-2782,

29. Burni T \& Hussain F (2011). Diversity in arbuscular mycorrhizal morphology in some medicinal plants of family Lamiaceae. Pak. J. Bot. 43(3): 17891792

30. Shaheen H, Shinwari ZK, Qureshi RA \& Ullah Z (2012). Indigenous Plant Resources and Their Utilization Practices in Village Populations of Kashmir Himalayas. Pak J Bot 44, 739745. 